\title{
Correction to: Polyphenols from Sugarcane Vinasses, Quantification, and Removal Using Activated Carbon After Biochemical Treatment in Laboratory-Scale Thermophilic Upflow Anaerobic Sludge Blanket Reactors
}

\author{
José Antonio Contreras-Contreras • Marisela \\ Bernal-González • Julio Alberto Solís-Fuentes • María \\ del Carmen Durán-Domínguez-de-Bazúa (D)
}

Published online: 20 August 2020

(C) Springer Nature Switzerland AG 2020
Correction to: Water Air Soil Pollut (2020) 231:401

https://doi.org/10.1007/s11270-020-04733-5

The original version of this article unfortunately contained an error.

The name of the corresponding author was incorrectly tagged in the published online paper.

The first name should be María del Carmen and the family name should be Durán-Domínguez-de-Bazúa.

The online version of the original article can be found at https://doi.org/10.1007/s11270-020-04733-5

J. A. Contreras-Contreras • M. Bernal-González •

M. d. C. Durán-Domínguez-de-Bazúa $(\triangle)$

Facultad de Química, Departamento de Ingeniería Química, Laboratorios de Ingeniería Química Ambiental y de Química Ambiental, Universidad Nacional Autónoma de México,

Conjunto E. Circuito de la Investigación Científica s/n Ciudad

Universitaria, 04510 Ciudad de Mexico, Mexico

e-mail: mcduran@unam.mx

\section{J. A. Solís-Fuentes}

Instituto de Ciencias Básicas, Universidad Veracruzana, Xalapa de Enríquez, Veracruz, Mexico
The in-text citation (Calle et al., 2000) found at the second page left column should be substituted by (Rosillo-Calle et al., 2000) without accent on the letter e. The reference corresponding to Rosillo-Calle et al., 2000, in page 11 right column, should be located after Rincón-Acelas reference and not before (alphabetical order) and please correct Rosille-Callé to Rosillo-Calle, that is:

Rosillo-Calle, F., Bajay, S. V., \& Rothman, H. (2000). Industrial uses of biomass energy: The example of Brazil. London and New York: Taylor and Francis. Amazon sells this book.

Publisher's Note Springer Nature remains neutral with regard to jurisdictional claims in published maps and institutional affiliations. 